\title{
Hematopoietic cells expressing the peripheral cannabinoid receptor migrate in response to the endocannabinoid 2-arachidonoylglycerol
}

\author{
Meritxell Alberich Jordà, Sandra E. Verbakel, Peter J. M. Valk, Yolanda V. Vankan-Berkhoudt, Mauro Maccarrone,
} Allessandro Finazzi-Agrò, Bob Löwenberg, and Ruud Delwel

\begin{abstract}
Cb2 is a novel protooncogene encoding the peripheral cannabinoid receptor. Previous studies demonstrated that 2 distinct noncoding first exons exist: exon-1A and exon-1B, which both splice to proteincoding exon-2. We demonstrate that in retrovirally induced murine myeloid leukemia cells with proviral insertion in $\mathrm{Cb2}$, exon-1B/exon-2 Cb2 messenger RNA levels have been increased, resulting in high receptor numbers. In myeloid leukemia cells without virus insertion in this locus, low levels of only exon-1A/exon-2 Cb2 transcripts were present and receptors could not be detected. To elucidate the function of $\mathrm{Cb} 2$ in myeloid leukemia cells,
\end{abstract}

a set of in vitro experiments was carried out using 32D/G-CSF-R (granulocyte colony-stimulating factor receptor) cells transfected with exon-1B/exon-2 Cb2 complementary DNA and a myeloid cell line carrying a virus insertion in $\mathrm{Cb2}$ (ie, NFS 78). We demonstrate that a major function of the $\mathrm{Cb} 2$ receptor is stimulation of migration as determined in a transwell assay. Exposure of Cb2-expressing cells to different cannabinoids showed that the true ligand for $\mathrm{Cb} 2$ is 2-arachidonoylglycerol (2-AG), which may act as chemoatractant and as a chemokinetic agent. Furthermore, we observed a significant synergistic activity between 2-AG and interleukin-3 or G-CSF, suggesting cross-talk between the different receptor systems. Radioactive-ligand binding studies revealed significant numbers of $\mathrm{Cb} 2$ receptors in normal spleen. Transwell experiments carried out with normal mouse spleen cells showed 2-AG-induced migration of B220-, CD19-, immunoglobulin M-, and immunoglobulin D-expressing $B$ lymphocytes. Our study demonstrates that a major function of $\mathrm{Cb} 2$ receptor expressed on myeloid leukemia cells or normal splenocytes is stimulation of migration. (Blood. 2002;99:2786-2793)

(๑) 2002 by The American Society of Hematology

\section{Introduction}

Two distinct cannabinoid receptors have previously been identified: the central ${ }^{1}(\mathrm{Cb} 1)$ and the peripheral $(\mathrm{Cb} 2)$ cannabinoid receptor. ${ }^{2}$ In retrovirally induced murine leukemia, proviral insertions frequently occur in the gene encoding $\mathrm{Cb} 2$, suggesting that the peripheral cannabinoid receptor is an oncoprotein. . $^{3,4}$ The cannabinoid receptors belong to the superfamily of 7-transmembrane $\mathrm{G}$ protein-coupled receptors (GPCRs). Several GPCRs have been shown to be involved in cell growth and oncogenesis as the result of aberrant expression. ${ }^{5-7}$ Examples of GPCRs with transforming ability are the $\alpha 1 \mathrm{~B}$-adrenergic, ${ }^{8}$ thrombin, ${ }^{9}$ and serotonin $1 \mathrm{c}$ receptors ${ }^{10}$ and the receptor encoded by MAS oncogene. ${ }^{11,12}$ Our previous observation that $C b 2$ is a common virus integration site suggests that aberrant expression of this 7-transmembrane receptor may be a critical event in transformation in certain cases of leukemia. ${ }^{3}$ The protein-coding region of $\mathrm{Cb} 2$ is located on a single exon (exon-2) of approximately 4 kilobases. Recently we identified 2 distinct $5^{\prime}$ noncoding exons (ie, exon-1A and exon-1B) previously designated exon- 1 and exon- $1^{\prime}$, respectively. ${ }^{3}$ In the study presented here we first carried out experiments to investigate Cb2 messenger RNA (mRNA) transcripts and protein expression in leukemic cells with or without retroviral insertion in the $\mathrm{Cb} 2$ locus. Secondly, we performed studies to determine the function of the peripheral cannabinoid receptor when overexpressed in myeloid cells.

From the Institute for Hematology, Erasmus University Rotterdam, The Netherlands; and Department of Experimental Medicine and Biochemical Sciences, University of Rome "Tor Vergata," Rome, Italy.

Submitted April 10, 2001; accepted December 13, 2001.

Supported by the Dutch Cancer Foundation Koningin Wilhelmina Fonds, The Netherlands Organisation for Scientific Research (NWO), and the Royal Dutch Academy of Sciences (KNAW).
GPCRs have been related to many functions, including cell proliferation, maturation, survival, apoptosis, or migration. ${ }^{6,13,14}$ In the present study, we investigated the function of the peripheral cannabinoid receptor when overexpressed on myeloid cells (ie, 32D/G-CSF-R [granulocyte colony-stimulating factor receptor]) in which we overexpressed exon-1B/exon-2 Cb2 splice variant and a myeloid leukemia cell line containing a virus insertion in the $\mathrm{Cb} 2$ locus, NFS 78. We also wished to determine which of the large panel of $\mathrm{Cb} 2$ ligands that have been identified previously is the true agonist of the receptor. We investigated the effects of natural $\left(\delta^{8}\right.$-tetrahydrocannabinol $\left[\delta^{8}\right.$-THC $],{ }^{15} \delta^{9}$-THC, ${ }^{16}$ cannabinol, ${ }^{17}$ and cannabidiol $^{16}$ ), synthetic (WIN 55212-2 ${ }^{18}$ and CP55940 ${ }^{19}$ ), and endogenous (2-arachidonoylglycerol [2-AG], ${ }^{20,21}$ anandamide [AEA $],{ }^{22,23} \mathrm{~N}$-palmitoylethanolamine $[\mathrm{PEA}],{ }^{24}$ and $\mathrm{N}$-acylethanolamine $[\mathrm{POEA}]^{24}$ ) cannabinoids. We show that $2-\mathrm{AG}$ is the most potent agonist for the $\mathrm{Cb} 2$ receptor and that a major function of 2-AG is stimulation of migration. We further studied whether 2-AG acts as a chemotactic or chemokinetic agent and whether cytokines, such as interleukin-3 (IL-3) or G-CSF, increase the stimulatory effect of 2-AG. Because the other cannabinoid ligands are also able to bind to the peripheral cannabinoid receptor, we investigated whether these compounds either synergize or antagonize with the stimulatory effect of 2-AG. Next, we investigated $\mathrm{Cb} 2$ receptor expression and function in normal spleen and thymus. We show

Reprints: Ruud Delwel, Institute for Hematology, Erasmus University Rotterdam, Dr Molewaterplein 50, 3015GE Rotterdam, The Netherlands; e-mail: delwel@hema.fgg.eur.nl.

The publication costs of this article were defrayed in part by page charge payment. Therefore, and solely to indicate this fact, this article is hereby marked "advertisement" in accordance with 18 U.S.C. section 1734.

(c) 2002 by The American Society of Hematology 
that $\mathrm{Cb} 2$ receptors are normally expressed on $\mathrm{B} 220^{+}$splenocytes and that the major function of the peripheral cannabinoid receptor on these B lymphocytes is regulation of migration as well.

\section{Materials and methods}

Cell lines

The myeloid cell lines NFS 58, 61, 70, and 78 were established from Cas-Br-M murine leukemia virus-initiated primary tumors. ${ }^{25}$ The 32D/GCSF-R cell line $^{26}$ was kindly donated by Prof Dr I. P. Touw (Erasmus University Rotterdam). The cell lines were cultured in RPMI 1640 medium (Life Technologies, Breda, The Netherlands) supplemented with penicillin $(100 \mathrm{IU} / \mathrm{mL})$, streptomycin $(100 \mathrm{ng} / \mathrm{mL})$, murine IL-3 $(10 \mathrm{ng} / \mathrm{mL})$, and $10 \%$ fetal calf serum (Life Technologies).

\section{Ligands and cannabinoid ligands}

Recombinant human stromal cell-derived factor (SDF-1 $\alpha$ ) was obtained from R\&D Systems (Uithoorn, The Netherdands). The Cb2 ligands used were 2-AG, AEA, WIN 55212-2, cannabinol, cannabidiol, $\delta^{8}$-THC, and $\delta^{9}$-THC from Sigma (Zwijndrecht, The Netherlands). PEA and POEA are from ICN Biomedicals (Zoetermeer, The Netherlands) and CP55940 from Pfizer (Groton, CT). Cb1-specific antagonist SR141716 and Cb2-specific antagonist SR144528 were kindly donated by Dr Casellas (Sanofi Recherche, Montpellier, France).

\section{Cb2 expression constructs and transfection of 32D/G-CSF-R cells}

Cb2 exon-1B plus exon-2, which was hemagglutinin (HA)-tagged at the $5^{\prime}$ end (EcoRI/NcoI), was cloned as HindIII/BamHI fragment into HindIII/ $B g I I I$ sites of pLNCX. The expression construct was transfected into 32D/G-CSF-R by electroporation (230V, 100 microfarads, and 1000 milliseconds). Following gene transfer, cells were cultured in RPMI 1640 medium supplemented as above for 48 hours and then selected in neomycin at concentrations of $0.8 \mathrm{mg} / \mathrm{mL}$. Neomycin-resistant clones were expanded. To study $C b 2$ mRNA expression, ribonuclease (RNase) protection analysis was applied. Because mouse $\mathrm{Cb} 2$-specific antibodies are not yet available and $\mathrm{HA}$ antibodies are not capable of detecting $\mathrm{HA}-\mathrm{Cb} 2, \mathrm{Cb} 2$ protein expression was analyzed by ligand binding (see below).

\section{RNase protection analysis}

RNase protection analysis was performed as described previously. ${ }^{27}$ Total cellular RNA was prepared from kidney, heart, spleen, and thymus by homogenizing tissue cells in $4 \mathrm{M}$ guanidium thiocyanate, followed by phenol-chloroform extraction and isopropanol precipitation. ${ }^{28}$ RNA from NFS cell lines and 32D/G-CSF-R-transfected cells was isolated using $4 \mathrm{M}$ guanidium thiocyanate or Trizol Reagent (Life Technologies). The RNA samples were subjected to an RNase protection assay, essentially as described by the supplier (Promega, Leiden, The Netherlands). A 249-base pair (bp) fragment (bp -147 to bp +102 of $C b 2$ complementary DNA [cDNA], probe P) (Figure 1A) was cloned into a pBluescript II SK + vector and linearized with HindIII. A radiolabeled GAPDH RNA fragment was used as a control..$^{29}$

\section{Membrane preparation and $\left[{ }^{3} \mathrm{H}\right] \mathrm{CP} 55940$ binding assays}

Frozen cell and tissue pellets were kept at $-80^{\circ} \mathrm{C}$ until use. Pellets were thawed and suspended in assay buffer $(50 \mathrm{mM}$ Tris- $\mathrm{HCl}[\mathrm{pH} 7.0], 1 \mathrm{mM}$ ethylenediaminetetraacetic acid, $3 \mathrm{mM} \mathrm{MgCl}_{2}, 100 \mu \mathrm{M}$ phenylmethylsulfonyl fluoride $[\mathrm{pH} 7.4]$ containing $0.1 \%$ bovine serum albumin [Serva, Heidelberg, Germany]), and membrane suspensions were homogenized and centrifuged at $10000 \mathrm{~g}$ for 10 minutes $\left(4^{\circ} \mathrm{C}\right)$. Pellets were then resuspended in $5 \mathrm{~mL}$ in assay buffer, homogenized using a Potter-Elvejhem homogenizer, and resuspended in assay buffer at a final membrane concentration equivalent to $10^{6}$ cells per milliliter. For binding experiments, $160 \mu \mathrm{L}$
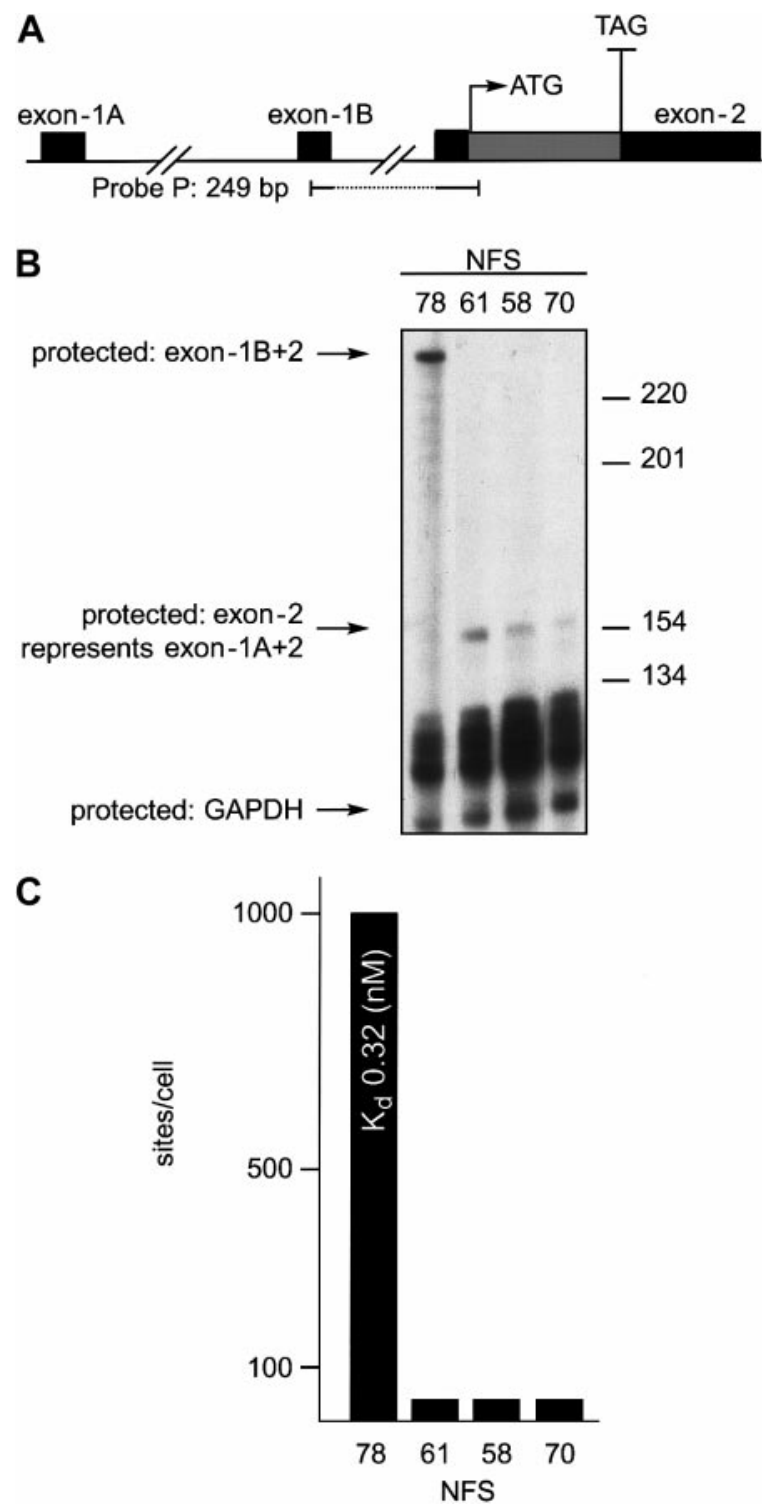

Figure 1. Expression of distinct $\mathrm{Cb} 2 \mathrm{mRNA}$ splice variants and determination of receptor binding sites in mouse myeloid leukemia cell lines. (A) Genomic organization of mouse $\mathrm{Cb} 2$. The gray box represents the $\mathrm{Cb} 2$ protein-coding region. Two distinct splice variants have been identified: exon-1A/exon-2 and exon-1B exon-2. The 249 nucleotide RNA probe (probe $P$ ) representing exon-1B/exon-2 that was used for RNase protection analysis is indicated. (B) RNase protection analysis on distinct myeloid cell lines using probe $\mathrm{P}$ (see panel A). (C) Cb2 receptor density and receptor affinity for CP55940 on the NFS cell lines was assessed by saturation radioligand receptor binding experiments using $\left[{ }^{3} \mathrm{H}\right] \mathrm{CP} 55940 . K_{d}$ is added to the columns.

membrane suspension $\left(10^{6}\right.$ cells $\left./ \mathrm{mL}\right)$ was incubated in 96-well plates (flat-bottom plates, Greiner) with $20 \mu \mathrm{L}\left[{ }^{3} \mathrm{H}\right] \mathrm{CP} 55940$ (DuPont-New England Nuclear) in concentrations ranging from $0.2 \mathrm{nM}$ to $1.2 \mathrm{nM}$ and 20 $\mu \mathrm{L}$ assay buffer for total binding or assay buffer containing $10^{-5} \mathrm{M}$ nonlabeled CP55940 to assess nonspecific binding. Mixtures $(200 \mu \mathrm{L}$ final volume) were incubated at $30^{\circ} \mathrm{C}$ for 50 minutes, after which suspensions were filtrated over Unifilter GF/B plates using a Filtermate-196 Harvester (Packard) and washed twice for 5 seconds with $200 \mu \mathrm{L}$ ice-cold washing buffer (50 mM Tris- $\mathrm{HCl}$ [pH 7.0] containing $0.25 \%$ bovine serum albumin). Filtration plates were sealed at the bottom, $25 \mu \mathrm{L}$ scintillation fluid (Microscint-O, Packard) was added per well, and radioactivity was counted in a TopCount scintillation counter (Canberra Packard). Saturation curves produced identical affinities for $\left[{ }^{3} \mathrm{H}\right] \mathrm{CP} 55940$ (affinity dissociation constant $\left[K_{\mathrm{d}}\right]$ ranged from 0.25 to $0.5 \mathrm{nM}$ ). Saturation plots were constructed by plotting specific binding (ie, total binding minus nonspecific binding) 
against label concentration, ranging from $0.2 \mathrm{nM}$ to $1.2 \mathrm{nM}$, after which nonlinear curve fitting was done to estimate $\mathrm{B}_{\max }$ and affinity. In parallel, Scatchard plots were constructed by plotting the ratio-specific binding over free-label concentration against specific binding. $\mathrm{Cb} 2$ binding sites with spleen cells or thymocytes (Figure 7B) were assessed in triplicate using one radioligand concentration of CP55940 (1 nM). Nonspecific binding was determined in the presence of excess nonradioactive CP55940 $\left(10^{-6} \mathrm{M}\right)$, and specific binding was expressed as femtomoles per $10^{6}$ cells (Figure 7C).

\section{Migration assay}

Migration assays were performed using $6.5 \mathrm{~mm}$-diameter transwells with 5 $\mu \mathrm{m}$ pore size (Corning Costar, Amsterdam, The Netherlands). The cells used for the migration assay were NFS 58, 61 and 78 cells, transfected 32D/G-CSF-R cells, and spleen and thymus cells from male FVB mice. Mice were killed by inhalation of $\mathrm{CO}_{2}$. Spleen and thymus were isolated immediately and placed on RPMI 1640 medium. Single-cell suspension was prepared using $70-\mu \mathrm{m}$ nylon cell strainer (Falcon, NJ). For migration assay, $1 \times 10^{5}$ or $2 \times 10^{5}$ cells were washed twice with Hanks balanced salt solution medium, resuspended in $100 \mu \mathrm{L}$ migration medium (Iscoves modified Dulbecco medium plus $0.5 \%$ bovine serum albumin), and placed in the upper chamber of the transwells with or without presence of ligand. In the lower chamber, $600 \mu \mathrm{L}$ migration medium with or without ligand was placed. After 4 hours' incubation at $37^{\circ} \mathrm{C}$ and $5 \% \mathrm{CO}_{2}$, the upper chamber was removed and the number of migrated cells was determined using a CASY1/TTC cell counter (Schärfe System, Germany).

\section{Flow cytometric analysis}

Spleen cells that migrated to the lower chamber in the migration assay were immunophenotyped using a FACSCalibur flow cytometer (Becton Dickinson, Mountain View, CA). The following rat monoclonal antibodies were used in indirect immunofluorescence assays: RA3-6B2 (anti-B220/ CD45R), Ter119 (LY-76), 59-AD2.2 (anti-Thy-1), and KT3 (anti-CD3). A fluorescein isothiocyanate-conjugated goat anti-rat immunoglobulin (Ig) (Nordic Immunological Labs, Tilburg, The Netherlands) was used as a second-step reagent. Immunophenotyping with double or triple labeling was performed combining the mentioned antibodies with allophycocyaninconjugated anti-B220/CD45R (RA3-6B2), phycoerythrin-conjugated antiIgD (Southern Biotechnology, Birmingham, AL), anti-CD19 (1D3), and anti-CD11c (HL3), as well as biotinylated anti-IgM (II/41), using streptavidin-allophycocyanin as a second step (Pharmingen, San Diego, CA).

\section{Results}

\section{Cb2 expression analysis in myeloid leukemic cell lines}

The protein-coding region for the peripheral cannabinoid receptor is located on exon-2 of the $\mathrm{Cb} 2$ gene (Figure 1A). Two distinct $C b 2$ splice variants have been identified, which both comprise the $C b 2$ receptor coding exon but contain different nonprotein-coding first exons: exon-1A or exon-1B (Figure 1A). To determine which splice variant is present in myeloid cell lines, RNase protection was performed using a 249-bp polymerase chain reaction product (probe P) overlapping exon-1B (101 nucleotides) and exon-2 (148 nucleotides) (Figure 1A). A protected band of 249 nucleotides corresponding to exon-1B plus exon-2 Cb2 mRNA was identified in the myeloid cell line NFS 78 (Figure 1B), which contains a retroviral insertion in $\mathrm{Cb} 2$, whereas a 148 nucleotide exon-2protected fragment was identified in the other myeloid cell lines (Figure 1B). As demonstrated previously, this latter protected fragment represents exon-1A/exon-2 Cb2 transcript. ${ }^{3,27}$ Ligand binding studies using $\left[{ }^{3} \mathrm{H}\right] \mathrm{CP} 55940$ and Scatchard plot analysis revealed the presence of significant numbers of cannabinoid binding sites on NFS 78 cells, whereas receptors were not measurable on the other IL-3-dependent myeloid cell lines (Figure 1C).

The endocannabinoid 2-AG is the true ligand for $\mathrm{Cb} 2$ receptor and stimulates migration of Cb2-expressing myeloid cells

Next, we wished to determine the function of the peripheral cannabinoid receptor when overexpressed in myeloid cells and investigate which of the large panel of molecules capable of binding is the true ligand for $\mathrm{Cb} 2$. For this purpose we used the $\mathrm{Cb} 2$-overexpressing myeloid cell line NFS 78 as well as 2 clones of the 32D/G-CSF-R cell line in which we introduced exon-1B/ exon-2 Cb2 cDNA. High exon-1B/exon-2 Cb2 mRNA expression was demonstrated by RNase protection (Figure 2A), and ligand binding studies demonstrated excess of $\left[{ }^{3} \mathrm{H}\right] \mathrm{CP} 55940$ binding sites on exon-1B/exon-2 Cb2-transfected cells (Figure 2B). No exon-1B/ exon-2 $\mathrm{Cb} 2$ mRNA or ligand binding sites were detected in the vector control 32D/G-CSF-R cells (Figure 2).

Because $G$ protein-coupled receptors may function in cell mobility, we investigated in vitro migration in transwell assays. The following cannabinoid ligands were added to the lower chamber to test their capacity to induce chemotactic migration (1 $\mu \mathrm{M})$ : AEA, 2-AG, PEA, POEA, CP55940, $\delta^{8}$-THC, $\delta^{9}$-THC, WIN 55212-2, cannabinol, and cannabidiol; 2-AG and, to a lesser extent, AEA stimulated migration of Cb2-transfected 32D/G-CSF-R (Figure $3 \mathrm{~A}$ ). None of the other ligands were capable of stimulating migration of these $\mathrm{Cb} 2$-expressing cells (Figure 3A). In fact, in separate experiments using different concentrations of each of these ligands ( $1 \mathrm{nM}$ to $10 \mu \mathrm{M}) 2-\mathrm{AG}$ was the only potent inducer of


Figure 2. Messenger RNase protection analysis and ligand binding studies on transfected 32D/G-CSF-R cells. (A) RNase protection analysis using probe $P$ on 10 $\mu \mathrm{g}$ total mRNA from 4 distinct transfected 32D/G-CSF-R clones: 2 32D/G-CSF-R clones transfected with $\mathrm{Cb} 2$ exon-1B/exon-2 cDNA and 2 clones with control vector pLNCX. (B) Cb2 receptor density and receptor affinity for CP55940 on 2 Cb2 exon-1B/exon-2 clones and 2 empty vector control clones. Density and affinity were assessed by saturation radioligand receptor binding experiments using $\left[{ }^{3} \mathrm{H}\right] \mathrm{CP} 55940$. $K_{d}$ is added to the columns. 
Figure 3. In vitro migration of $\mathrm{Cb}$-expressing cells following exposure to cannabinoids. (A) Comparison of the chemoattractive effect of different cannabinoid ligands $(1 \mu \mathrm{M})$ on $C b 2$ exon-1B/exon-2-expressing 32D/G-CSF-R cells. Ligands were added to the lower chamber, and cells that migrated to the lower well were counted after 4 hours of incubation. Y-axis shows the percentage of migrated cells from an input of $1 \times 10^{5}$. (B) Effect of different concentrations of 2-AG when added to the lower chamber on the in vitro migration of Cb2-expressing 32D/G-CSF-R cells. Y-axis shows the percentage of migrated cells from an input of $1 \times 10^{5}$. (C) 2 -AG titration experiment using the myeloid cell line NFS 78. Y-axis shows the percentage of migrated cells from an input of $2 \times 10^{5}$. (D) Chemoattractive effect of $300 \mathrm{nM} 2-\mathrm{AG}$ $(\square)$ or nothing $(\square)$ on exon-1B/exon-2 Cb2-expressing cells versus non-Cb2-expressing cells. Y-axis shows percentage of migrated cells from an input of $2 \times 10^{5}$ cells. (E) Cb2-expressing $32 \mathrm{D} / \mathrm{G}-\mathrm{CSF}-\mathrm{R}$ cells were exposed to medium with or without 300 nM 2-AG added to the lower well; $100 \mathrm{nM} \mathrm{Cb1-specific} \mathrm{antago-}$ nist, SR141716, Cb2-specific antagonist, SR144528, or cells without antagonist as a control were placed on the upper well. Y-axis shows percentage of migration from an input of $1 \times 10^{5}$ cells.
A

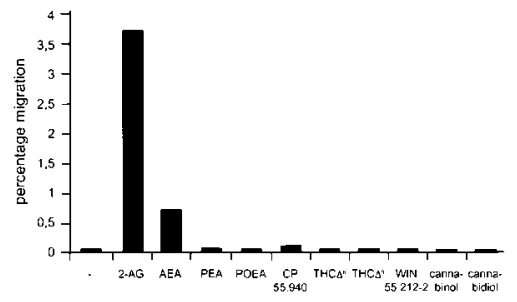

\section{C}
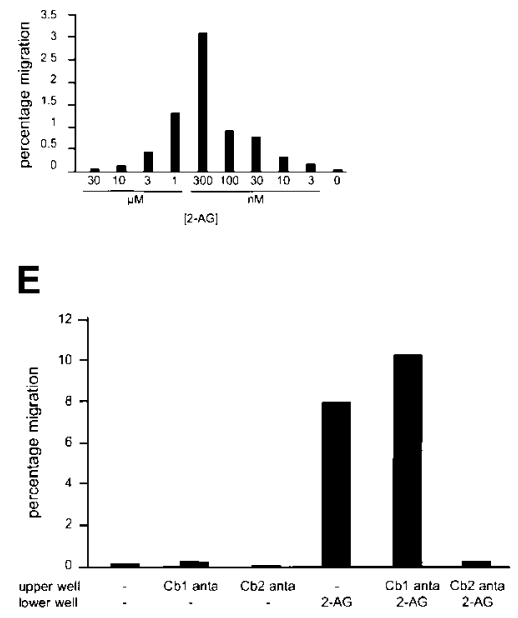

B
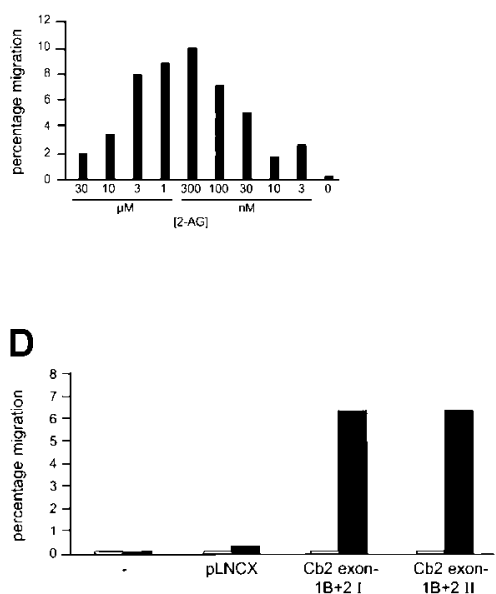

$\mathbf{E}$

migration at a optimal concentration of $300 \mathrm{nM}$ (Figure 3B-C).
Migration was shown to be specific because 32D/G-CSF-R parental cells as well as vector control-transfected 32D/G-CSF-R cells did not migrate in response to 2-AG (Figure 3D). Neither did we observe any migration using the cell lines NFS 58 and NFS 61 (data not shown), which were revealed to be negative in the $\left[{ }^{3} \mathrm{H}\right] \mathrm{CP} 55940$ binding assay (Figure 1C). Moreover, addition of SR144528 (100 $\mathrm{nM})$, a Cb2-specific antagonist, to the upper chamber abolished the 2-AG-mediated transwell migration of 32D/G-CSF-R/Cb2 cells completely, whereas the Cb1-specific antagonist SR141716 did not affect 2-AG-induced migration (Figure 3E).

\section{2-AG stimulates chemotaxis as well as chemokinesis of Cb2-expressing myeloid cells}

To investigate whether 2-AG is a chemokinetic as well as a chemotactic agent, in vitro migration experiments were carried out with 2-AG added to the lower chamber, the upper chamber, or both. When 2-AG was added to the upper and lower chamber simultaneously, approximately $50 \%$ migration was observed as compared with the chemotactic experiment (ie, with 2-AG added to the lower well only) (Figure 4). No cells migrated when 2-AG was added to the upper well only. In comparison, 32D/G-CSF-R/Cb2 cells, which express the CXC chemokine receptor 4 (CXCR4) endogenously, migrated when the CXCR4 ligand SDF- $1 \alpha$ was added to the lower chamber. However, no chemokinetic mobility was observed when SDF-1 $\alpha$ was added to both chambers (Figure 4).

\section{Natural and synthetic cannabinoids inhibit 2-AG-induced migration, whereas endocannabinoids have no effect}

Because the endocannabinoids (AEA, PEA, POEA) as well as the natural $\left(\delta^{8}-\mathrm{THC}, \delta^{9}\right.$-THC) and the synthetic cannabinoid ligands (CP55940, WIN 55212-2) are capable of binding to the peripheral cannabinoid receptor, we wondered whether these compounds could either synergize with $2-\mathrm{AG}$ or antagonize the effect of this ligand in a migration assay. The synthetic cannabinoids CP55940 and WIN 55212-2 as well as $\delta^{8}$-THC and $\delta^{9}$-THC completely abolished 2-AG-induced chemoattraction of Cb2-transfected 32D/ G-CSF-R cells when added either to the lower (Figure 5A) or the upper chamber in a transwell assay (data not shown). On the other hand, AEA, PEA, and POEA did not affect 2-AG-induced chemoattraction (Student $t$ test, $P>.05$ ) of cells when either added to the lower (Figure $5 \mathrm{~B}$ ) or to the upper chamber in a migration assay (not shown).

\section{Effects of 2-AG in combination with IL-3 or G-CSF on migration of Cb2-expressing cells}

To study whether $\mathrm{Cb} 2$ receptor ligands may synergize with other ligands that can activate 32D/G-CSF-R cells, we carried out migration experiments using 2-AG in combination with IL-3 or G-CSF. No migration was observed when 32D/G-CSF-R/Cb2 cells were exposed to IL-3 or G-CSF alone in a transwell assay. However, addition of 2-AG with IL-3 or G-CSF showed a significant increase in the migration rate of these cells as compared with experiments using 2-AG as a single agent (Figure 6). The

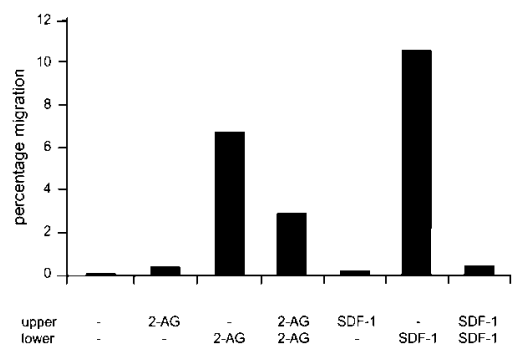

Figure 4. Chemotaxis versus chemokinesis of $\mathrm{Cb} 2$-expressing cells in response to 2-AG or SDF-1 using a transwell assay. Cb2-transfected 32D/G-CSF-R cells, which naturally express CXCR4, were placed in the upper well with or without 2-AG or SDF-1 $\alpha$. Migration medium with or without ligand was placed in the lower well. Y-axis shows percentage of migration from an input of $1 \times 10^{5}$ cells. 

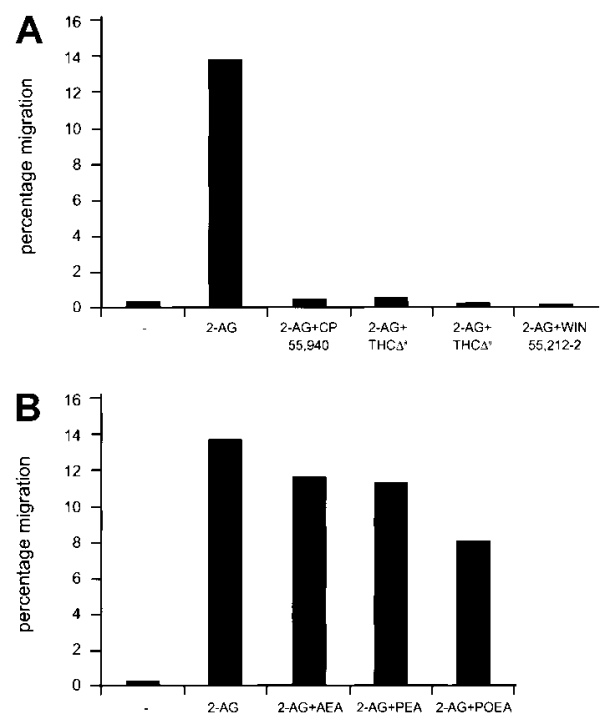

Figure 5. Effect of endocannabinoids and natural and synthetic cannabinoid ligands on the 2-AG-induced mobilization of cells. (A) Cb2-transfected 32D/GCSF-R cells were exposed to 2-AG or 2-AG plus CP55940, $\delta^{9} \mathrm{THC}, \delta^{8} \mathrm{THC}$, or WIN55212-2 in a chemotactic experiment. Y-axis shows percentage of migration from an input of $2 \times 10^{5}$ cells. (B) Cb2-transfected 32D/G-CSF-R cells were placed in the upper well, and migration medium containing 2-AG or 2-AG in combination with $A E A, P E A$, and POEA was added to the lower chamber. $Y$-axis shows percentage of migration from an input of $2 \times 10^{5}$ cells.

same effect was observed when NFS 78 cells were exposed to 2-AG and IL-3 (data not shown).

\section{Distinct $\mathrm{Cb2}$ mRNA splice variants and protein levels in} mouse spleen and thymus

The functional assays carried out so far were performed with cells that overexpress $\mathrm{Cb} 2$ receptor. Before elucidating whether naturally expressing $\mathrm{Cb} 2$ cells migrate following 2-AG exposure as well, we first investigated which hematopoietic organs express $\mathrm{Cb} 2$. RNase protection analysis was carried out on thymus and spleen mRNA using probe P (Figure 1A). A protected band of 249 nucleotides, corresponding to exon-1B plus exon-2 Cb2 mRNA, was identified in spleen (Figure 7A), whereas a 148 nucleotide exon-2-protected fragment, representing exon-1A/exon-2 $\mathrm{Cb} 2$ transcript, was identified in spleen and thymus (Figure 7A). $\mathrm{Cb} 2$ mRNA was not detectable in the other tissues investigated ${ }^{27}$ (Figure 7A). To study the presence of $\mathrm{Cb} 2$ binding sites in spleen and thymus, a binding assay was carried out using a saturated concentration of $1 \mathrm{nM}\left[{ }^{3} \mathrm{H}\right] \mathrm{CP} 55940$ (determined on NFS 78 [Figure 1C]). The experiment in Figure 7B demonstrates that $\left[{ }^{3} \mathrm{H}\right] \mathrm{CP} 55940$ binding is observed in spleen and not in thymus of normal FVB mice, which is in agreement with previous studies..$^{30,31}$

\section{Migration of Cb2-expressing spleen cells following 2-AG stimulation}

To investigate whether naturally expressing $\mathrm{Cb} 2$ cells migrate following 2-AG exposure as well, spleen cells from FVB mice were studied using a transwell assay. A titration experiment showed optimal migration of spleen cells in the presence of $300 \mathrm{nM} 2-\mathrm{AG}$ (data not shown). Moreover, this migration could be blocked by addition of $\mathrm{Cb} 2$-specific antagonist to the upper well but not by addition of Cb1-specific antagonist (Figure 7C). No significant migration was evident of thymocytes in transwells (data not shown). Immunophenotyping by flow cytometric analysis of the 2-AG-induced migrated spleen cells compared with spontaneously migrated spleen cells revealed that the cells were B220 ${ }^{+}$. Double staining revealed that these $\mathrm{B} 220^{+}$cells expressed CD19, IgM, and IgD (Figure 7D). In addition, these cells were CD11c ${ }^{-}$, indicating that the spleen-migrated cells were $\mathrm{B}$ lymphocytes and not $\mathrm{B} 220^{+} / \mathrm{CD} 11 \mathrm{c}^{+}$dentritic cells (Figure 7D).

\section{Discussion}

In the study presented here, we demonstrate that 2 distinct $\mathrm{Cb} 2$ mRNA splice variants exist in the mouse, each composed of the same protein-encoding exon- 2 but with a different nonproteincoding first exon. In most myeloid leukemia cell lines $C b 2$ exon-1A/exon-2 is expressed, which correlates with low protein expression. On the other hand, in mouse leukemia NFS 78, retroviral insertion has occurred $5^{\prime}$ of exon- $1 \mathrm{~B},{ }^{3,32}$ resulting in the expression of high levels of $C b 2$ exon-1B/exon- 2 mRNA and the appearance of $\mathrm{Cb} 2$ proteins on the cell surface. $\mathrm{Cb} 2$ receptors are also present on normal spleen cells, which express both $\mathrm{Cb} 2$ splice variants: exon-1A/exon-2 and exon-1B/exon-2. On the other hand, thymocytes only express $C b 2$ exon-1A/exon-2 splice variants, which are not accompanied by the presence of detectable numbers of ligand binding sites. These data suggest that in the cells studied here, $\mathrm{Cb} 2$ protein may be translated from exon-1B/exon-2 transcripts rather than from exon1A/exon 2 mRNAs. These results may be explained by a regulatory mechanism of translation involving the noncoding first exons of $\mathrm{Cb}$. Although several mechanisms of translational control involving noncoding mRNA have been described, ${ }^{33-36}$ the function of the 2 first exons in $C b 2$ is currently unknown. Whether and how these nonprotein-coding exons may regulate protein expression is subject to future investigations.

Oncogenic transformation by GPCRs may be caused either by structural alteration of the receptor itself or by deregulated presentation of the ligands. . $^{87,38} \mathrm{We}$ previously demonstrated that retroviral insertion in the $\mathrm{Cb} 2$ locus occurs frequently in myeloid leukemias in mice. ${ }^{3,32}$ The data presented here suggest that proviral insertion in $\mathrm{Cb} 2$ in myeloid leukemia cells may result in the selective expression of particular splice variants and overexpression of the peripheral cannabinoid receptor. GPCRs have been related to a variety of cellular functions, including cell proliferation, differentiation, survival, and migration..$^{39,40}$ To study the role of the peripheral cannabinoid receptor when overexpressed on myeloid cells, we investigated the effects of cannabinoid ligands on the myeloid cell line NFS 78 and on 32D/G-CSF-R cells transfected with the $C b 2$ exon-1B/exon-2 splice variant. We demonstrate that stimulation of $\mathrm{Cb} 2$-overexpressing cells by its potent agonist 2-AG induces migration in vitro at nanomolar concentrations. Given the role of $\mathrm{Cb} 2$ receptor in migration in vitro, we investigated whether 2-AG may act as a chemotactic as well as a

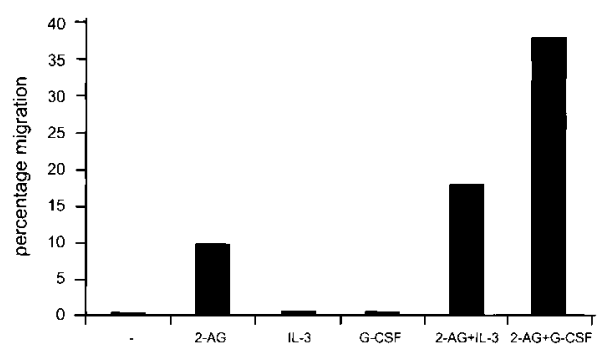

Figure 6. Synergy between 2-AG and IL-3 or G-CSF in migration stimulation. Cb2-transfected 32D/G-CSF-R cells were added to the upper chamber in a migration assay. Cells were exposed to migration medium present at the lower well containing 2-AG with or without IL-3 or G-CSF. Y-axis shows percentage of migration from an input of $2 \times 10^{5}$ cells. 
Figure 7. $\mathrm{Cb} 2$ expression and function in normal spleen and thymus. (A) RNase protection on $10 \mu \mathrm{g}$ total mouse mRNA isolated from several organs. The protected fragments were 249 nucleotides (exon-1B/exon-2 Cb2 mRNAprotected) or 148 nucleotides (exon-2 Cb2 mRNA-protected, representing exon-1A/exon-2). A GAPDH probe was used for normalization of the signals. (B) Receptor density (femtomoles per $10^{6}$ cells) on spleen cells and thymocytes was assessed by measuring specific binding of $\left[{ }^{3} \mathrm{H}\right] \mathrm{CP} 55940(1 \mathrm{nM})($ see "Materials and methods"). (C) Effect of Cb1-specific antagonist SR141716 o Cb2-specific antagonist SR144528 on spontaneous or 2-AG-induced migration of spleen cells. Antagonists and 2-AG were placed in the wells as indicated under the figure. Y-axis shows percentage of migration from an input of $2 \times 10^{5}$ spleen cells. (D) Immunophenotyping of 2-AG-induced migrated spleen cells versus spontaneous spleen-migrated cells using flow cytometry.
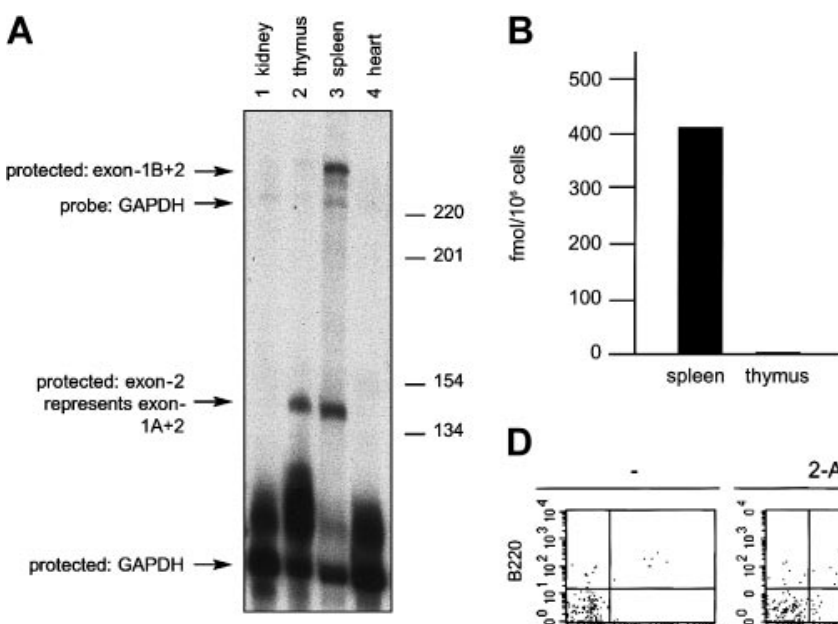

D
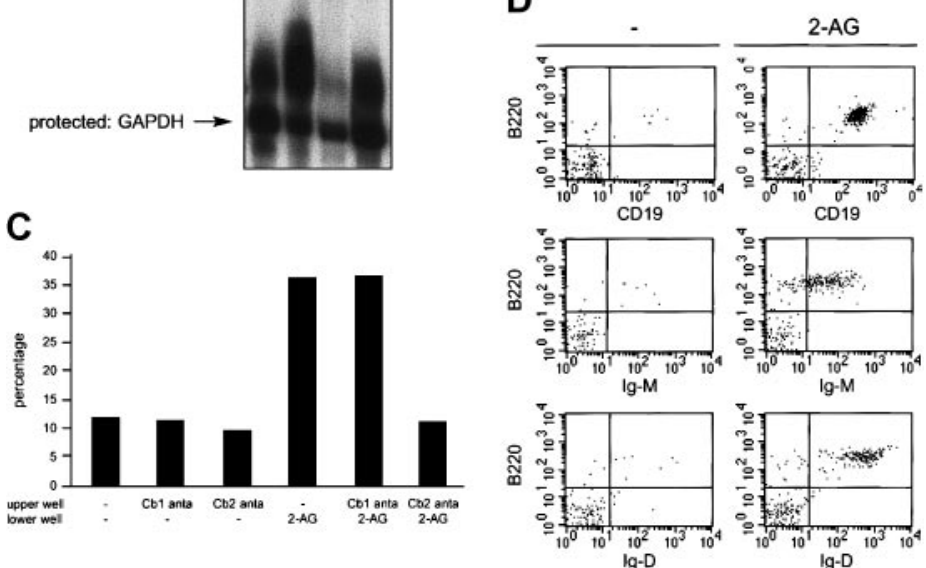
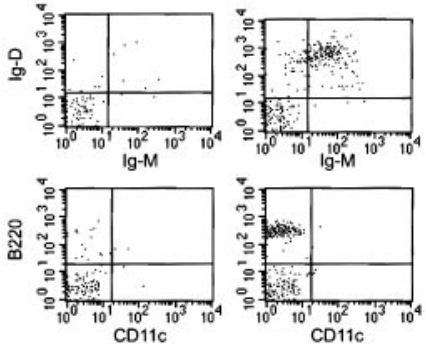

chemokinetic agent. In contrast to SDF- $1 \alpha$, which is a chemoattractant that acts via CXCR4, ${ }^{41-45}$ 2-AG may stimulate both chemotaxis (directional migration) and chemokinesis (random migration), a behavior that has been described for other receptors as well. ${ }^{46,47}$ Interestingly, a significant increase of migration was observed when $\mathrm{Cb} 2$-expressing 32D/G-CSF-R cells were exposed to 2-AG in combination with IL-3 as well as with G-CSF. This set of experiments demonstrates that activation of the peripheral cannabinoid receptor by the endocannabinoid 2-AG may occur in many ways, such as by chemoattraction, chemokinesis, and in synergy with cytokines. Therefore, aberrant $\mathrm{Cb} 2$ expression on myeloid leukemia cells may result in changes in mobilization and, subsequently, altered homing of the leukemic precursors in vivo. In future experiments we plan to investigate the in vivo mobility of $\mathrm{Cb} 2$-expressing bone marrow cells using $\mathrm{Cb} 2$ transgenic mice ${ }^{48}$ or bone marrow precursor cells that have been infected with viral vectors carrying the $C b 2$ gene.

We previously demonstrated that AEA is a potent inducer of proliferation in synergy with IL-3, granulocyte-macrophage CSF, or G-CSF. ${ }^{27}$ However, we and other investigators suggested that although AEA may be an activator of $\mathrm{Cb} 2$, this fatty acid has also a nonreceptor-mediated stimulating effect. ${ }^{27,49-51} \mathrm{We}$ could not detect an effect of 2-AG on survival or proliferation of $\mathrm{Cb} 2$-expressing cells (data not shown). However, this does not exclude the possibility that under different conditions or in combination with

other cytokines this receptor may have an effect on these functions. In fact, synergy between cytokines and chemokines has been previously observed in proliferation, differentiation, and survival assays as well as in migration experiments. ${ }^{27,52-55}$ Our findings showing increased migration when cells were stimulated with 2-AG and IL-3 as well as 2-AG and G-CSF strengthen the idea to further investigate the role that $2-\mathrm{AG}$ may have in combination with cytokines in proliferation, differentiation, or survival of leukemic progenitor cells.

Several cannabinoid ligands from different origin (natural, synthetic, and endogenous) have been proposed as the true cannabinoid ligands. ${ }^{19,20,22,56}$ In the present study we compared the effects of 2-AG with that of the other endocanabinoids (AEA, PEA, POEA), the natural cannabinoids ( $\delta^{8}$-THC, $\delta^{9}$-THC, cannabinol, cannabidiol), and the synthetic molecules (WIN55212-2, CP55940). Among the endocannabinoids, 2-AG was the most potent inducer of migration, supporting the idea that $2-\mathrm{AG}$ is the true endogenous ligand for the peripheral cannabinoid receptor. ${ }^{56-59} \mathrm{AEA}$, which was the first endogenous cannabinoid ligand isolated, ${ }^{22}$ shows similar binding affinity to the $\mathrm{Cb} 2$ receptor as 2-AG does. ${ }^{59}$ However, AEA only weakly stimulated migration of Cb2-expressing cells. This observation is in agreement with other studies demonstrating that AEA acts at the most as a partial agonist for the $\mathrm{Cb} 2$ receptor. ${ }^{59}$ The fact that the other endocannabinoids (PEA, POEA) did not stimulate migration or interfere with 2-AGinduced migration may be explained by much lower affinity of these 
compounds for the peripheral cannabinoid receptor. ${ }^{60}$ Neither CP55940, which has been considered a potent cannabinoid ligand and an inducer of migration, ${ }^{31,61}$ nor any of the other synthetic or natural cannabinoids were capable of stimulating cell mobility. In fact, we observed that most of the synthetic and natural cannabinoids interfere with 2-AG-stimulated $\mathrm{Cb} 2$ receptor activation and function. This observation may be in agreement with previous findings suggesting that cannabinoids may one way or the other impair the immune response. ${ }^{62}$ This interference may include impairment of macrophage functions, ${ }^{63,64}$ induction of an imbalance in T-cell CD4/CD8 ratio, ${ }^{65}$ alteration of immunoglobin production, ${ }^{66-68}$ down-regulation of natural killer cell activity, ${ }^{69,70}$ or perturbation in macrophage/T-cell cooperation. ${ }^{64,71}$ It will therefore be of relevance to exactly define which cells express $\mathrm{Cb} 2$ and respond to its endocannabinoid and further dissect the function of $\mathrm{Cb} 2$ receptor in the immune response. In this study we demonstrate that spleen cells migrating in response 2-AG were $\mathrm{B}_{22} 20^{+}, \mathrm{CD} 19^{+}, \mathrm{IgM}^{+}$, and $\mathrm{IgD}^{+}$, which is an agreement with previous studies showing that $\mathrm{Cb} 2$ receptor is mainly expressed on B lymphocytes. ${ }^{31,72,73}$ Furthermore, our data show that the $2-\mathrm{AG}$-induced migration could be completely blocked by SR144528, a Cb2-specific antagonist, but not by SR141716, a Cb1-specific antagonist, indicating that stimulation of migration occurs exclusively via $\mathrm{Cb} 2$ receptors. Previously, the function of the peripheral cannabinoid receptor has also been related to B-cell differentiation, as proposed by Carayon et al. ${ }^{31}$ These observations together with our findings suggest a role of the peripheral cannabinoid receptor in attraction, mobilization, or activation of $\mathrm{B}$ cells during the immune response.

\section{Acknowledgments}

We thank Dr R. Hendrix for excellent assistance during immunophenotyping of spleen-migrated cells and P. van Hennik for technical assistance in migration assays. We also thank Karola van Rooyen for preparation of the figures and Dr P. Casellas (Sanofi Recherche, Montpellier, France) for donation of the $\mathrm{Cb} 1$ and $\mathrm{Cb} 2$ receptorspecific antagonists SR141716 and SR144528, respectively.

\section{References}

1. Matsuda LA, Lolait SJ, Brownstein MJ, Young AC, Bonner TI. Structure of a cannabinoid receptor and functional expression of the cloned cDNA. Nature. 1990;346:561-564

2. Munro S, Thomas KL, Abu-Shaar M. Molecular characterization of a peripheral receptor for cannabinoids. Nature. 1993;365:61-65.

3. Valk PJ, Hol S, Vankan Y, et al. The genes encoding the peripheral cannabinoid receptor and $\alpha$-Lfucosidase are located near a newly identified common virus integration site, Evi11. J Virol. 1997;71:6796-6804.

4. Valk PJ, Vankan Y, Joosten M, et al. Retroviral insertions in Evi12, a novel common virus integration site upstream of Tra1/Grp94, frequently coincide with insertions in the gene encoding the peripheral cannabinoid receptor Cnr2. J Virol. 1999; 73:3595-3602.

5. Dhanasekaran N, Heasley LE, Johnson GL. G protein-coupled receptor systems involved in cell growth and oncogenesis. Endocr Rev. 1995;16: 259-270.

6. Dhanasekaran N, Tsim ST, Dermott JM, Onesime D. Regulation of cell proliferation by $\mathrm{G}$ proteins. Oncogene. 1998;17:1383-1394.

7. van Biesen $T$, Luttrell LM, Hawes BE, Lefkowitz RJ. Mitogenic signaling via G protein-coupled receptors. Endocr Rev. 1996;17:698-714.

8. Allen LF, Lefkowitz RJ, Caron MG, Cotecchia S. G-protein-coupled receptor genes as protooncogenes: constitutively activating mutation of the $\alpha$ 1B-adrenergic receptor enhances mitogenesis and tumorigenicity. Proc Natl Acad Sci U S A. 1991;88:11354-11358.

9. Whitehead I, Kirk H, Kay R. Expression cloning of oncogenes by retroviral transfer of CDNA libraries. Mol Cell Biol. 1995;15:704-710.

10. Julius D, Livelli TJ, Jessell TM, Axel R. Ectopic expression of the serotonin $1 \mathrm{c}$ receptor and the triggering of malignant transformation. Science. 1989;244:1057-1062.

11. Janssen JW, Steenvoorden AC, Schmidtberger $\mathrm{M}$, Bartram CR. Activation of the mas oncogene during transfection of monoblastic cell line DNA. Leukemia. 1988:2:318-320.

12. Young D, Waitches G, Birchmeier C, Fasano O, Wigler M. Isolation and characterization of a new cellular oncogene encoding a protein with multiple potential transmembrane domains. Cell. 1986;45:711-719.

13. Neptune ER, Bourne HR. Receptors induce che- motaxis by releasing the $\beta \gamma$ subunit of $\mathrm{Gi}$, not by activating Gq or Gs. Proc Natl Acad Sci U S A. 1997:94:14489-14494.

14. Offermanns S, Simon MI. Genetic analysis of mammalian G-protein signalling. Oncogene. 1998:17:1375-1381.

15. Howlett AC, Champion TM, Wilken GH, Mechoulam R. Stereochemical effects of $11-\mathrm{OH}-\delta$ 8-tetrahydrocannabinol-dimethylheptyl to inhibit adenylate cyclase and bind to the cannabinoid receptor. Neuropharmacology. 1990;29:161-165.

16. Devane WA, Dysarz FA III, Johnson MR, Melvin LS, Howlett AC. Determination and characterization of a cannabinoid receptor in rat brain. Mol Pharmacol. 1988;34:605-613.

17. Schatz AR, Lee M, Condie RB, Pulaski JT, Kaminski NE. Cannabinoid receptors CB1 and CB2 a characterization of expression and adenylate cyclase modulation within the immune system. Toxicol Appl Pharmacol. 1997;142:278-287.

18. Kuster JE, Stevenson JI, Ward SJ, D'Ambra TE, Haycock DA. Aminoalkylindole binding in rat cerebellum: selective displacement by natural and synthetic cannabinoids. J Pharmacol Exp Ther. 1993:264:1352-1363.

19. Little PJ, Compton DR, Johnson MR, Melvin LS, Martin BR. Pharmacology and stereoselectivity of structurally novel cannabinoids in mice. J Pharmacol Exp Ther. 1988;247:1046-1051.

20. Mechoulam R, Ben-Shabat S, Hanus L, et al. Identification of an endogenous 2-monoglyceride present in canine gut, that binds to cannabinoid receptors. Biochem Pharmacol. 1995;50:83-90.

21. Sugiura $T$, Kondo $S$, Sukagawa $A$, et al. 2-Arachidonoylglycerol: a possible endogenous cannab noid receptor ligand in brain. Biochem Biophys Res Commun. 1995;215:89-97.

22. Devane WA, Hanus L, Breuer A, et al. Isolation and structure of a brain constituent that binds to the cannabinoid receptor. Science. 1992;258: 1946-1949.

23. Devane WA. New dawn of cannabinoid pharmacology. Trends Pharmacol Sci. 1994;15:40-41.

24. Facci L, Dal Toso R, Romanello S, Buriani A, Skaper SD, Leon A. Mast cells express a periph eral cannabinoid receptor with differential sensitivity to anandamide and palmitoylethanolamide. Proc Natl Acad Sci U S A. 1995:92:3376-3380.

25. Holmes KL, Palaszynski E, Fredrickson TN, Morse HC, Ihle JN. Correlation of cell-surface phenotype with the establishment of interleukin 3-dependent cell lines from wild-mouse murine leukemia virus-induced neoplasms. Proc Nat Acad Sci U S A. 1985:82:6687-6691.

26. Dong F, van Buitenen C, Pouwels K, Hoefsloot LH, Lowenberg B, Touw IP. Distinct cytoplasmic regions of the human granulocyte colony-stimulating factor receptor involved in induction of proliferation and maturation. Mol Cell Biol. 1993;13: 7774-7781.

27. Valk $P$, Verbakel S, Vankan $Y$, et al. Anandamide, a natural ligand for the peripheral cannabinoid receptor is a novel synergistic growth factor for hematopoietic cells. Blood. 1997;90:1448-1457.

28. Sambrook J, Fritsch EF, Maniatis T. Molecular Cloning: A Laboratory Manual. Vol 1. 2nd ed. New York, NY: Cold Spring Harbor Laboratory Press; 1989.

29. Jenkins JR, Ayton $P$, Jones $T$, et al. Isolation of cDNA clones encoding the $\beta$ isozyme of human DNA topoisomerase II and localisation of the gene to chromosome 3p24. Nucleic Acids Res. 1992;20:5587-5592.

30. Lynn AB, Herkenham M. Localization of cannabinoid receptors and nonsaturable high-density cannabinoid binding sites in peripheral tissues of the rat: implications for receptor-mediated immune modulation by cannabinoids. J Pharmacol Exp Ther. 1994;268:1612-1623.

31. Carayon P, Marchand J, Dussossoy D, et al. Modulation and functional involvement of $\mathrm{CB} 2$ peripheral cannabinoid receptors during B-cell differentiation. Blood. 1998;92:3605-3615.

32. Valk PJ, Delwel R. The peripheral cannabinoid receptor, $\mathrm{Cb} 2$, in retrovirally-induced leukemic transformation and normal hematopoiesis. Leuk Lymphoma. 1998:32:29-43.

33. Kozak M. Interpreting cDNA sequences: some insights from studies on translation. Mamm Genome. 1996;7:563-574.

34. Kozak M. Initiation of translation in prokaryotes and eukaryotes. Gene. 1999;234:187-208.

35. Cazzola M, Skoda RC. Translational pathophysiology: a novel molecular mechanism of human disease. Blood. 2000;95:3280-3288.

36. Gray NK, Wickens M. Control of translation initiation in animals. Annu Rev Cell Dev Biol. 1998;14: 399-458.

37. Pollak MR, Brown EM, Chou YH, et al. Mutations in the human $\mathrm{Ca}(2+)$-sensing receptor gene cause familial hypocalciuric hypercalcemia and neonatal severe hyperparathyroidism. Cell. 1993 75:1297-1303. 
38. Simpson ER. Genetic mutations resulting in estrogen insufficiency in the male. Mol Cell Endocrinol. 1998;145:55-59.

39. Post GR, Brown JH. G protein-coupled receptors and signaling pathways regulating growth responses. FASEB J. 1996;10:741-749.

40. Gutkind JS. Cell growth control by G proteincoupled receptors: from signal transduction to signal integration. Oncogene. 1998;17:13311342.

41. Nagasawa T, Kikutani H, Kishimoto T. Molecular cloning and structure of a pre-B-cell growthstimulating factor. Proc Natl Acad Sci U S A. 1994;91:2305-2309.

42. Shirozu M, Nakano T, Inazawa J, et al. Structure and chromosomal localization of the human stromal cell-derived factor 1 (SDF1) gene. Genomics. 1995;28:495-500.

43. Bleul CC, Fuhlbrigge RC, Casasnovas JM, Aiuti A, Springer TA. A highly efficacious lymphocyte chemoattractant, stromal cell-derived factor 1 (SDF-1). J Exp Med. 1996;184:1101-1109.

44. Sanchez X, Cousins-Hodges B, Aguilar T, Gosselink P, Lu Z, Navarro J. Activation of HIV-1 coreceptor (CXCR4) mediates myelosuppression. J Biol Chem. 1997;272:27529-27531.

45. Aiuti A, Webb IJ, Bleul C, Springer T, GutierrezRamos JC. The chemokine SDF-1 is a chemoattractant for human CD34+ hematopoietic progenitor cells and provides a new mechanism to explain the mobilization of CD34+ progenitors to peripheral blood. J Exp Med. 1997;185:111-120.

46. Ho W, Uniyal S, Meakin SO, Morris VL, Chan BM. A differential role of extracellular signal-regulated kinase in stimulated PC12 pheochromocytoma cell movement. Exp Cell Res. 2001;263:254-264.

47. Wang F, Van Brocklyn JR, Hobson JP, et al. Sphingosine 1-phosphate stimulates cell migration through a $\mathrm{G}$ (i)-coupled cell surface receptor. Potential involvement in angiogenesis. J Biol Chem. 1999;274:35343-35350.

48. Joosten M, Valk PJM, Louz D, et al. Leukemic predisposition of Sca1/Cb2 transgenic mice. Exp Hematol. 2002;30:142-149.

49. Derocq JM, Bouaboula M, Marchand J, RinaldiCarmona M, Segui M, Casellas P. The endogenous cannabinoid anandamide is a lipid messenger activating cell growth via a cannabinoid receptor-independent pathway in hematopoietic cell lines. FEBS Lett. 1998;425:419-425.

50. Puffenbarger RA, Boothe AC, Cabral GA. Canna- binoids inhibit LPS-inducible cytokine mRNA expression in rat microglial cells. Glia. 2000;29:58 69.

51. Klein TW, Newton C, Friedman H. Cannabinoid receptors and the cytokine network. Adv Exp Med Biol. 1998;437:215-222.

52. Badache A, Hynes NE. Interleukin 6 inhibits proliferation and, in cooperation with an epidermal growth factor receptor autocrine loop, increases migration of T47D breast cancer cells. Cancer Res. 2001;61:383-391.

53. Hauzenberger D, Klominek J, Bergstrom SE, Sundqvist KG. T lymphocyte migration: the influence of interactions via adhesion molecules, the $\mathrm{T}$ cell receptor, and cytokines. Crit Rev Immunol. 1995; 15:285-316.

54. Simson L, Foster PS. Chemokine and cytokine cooperativity: eosinophil migration in the asthmatic response. Immunol Cell Biol. 2000;78:415422.

55. Zuckerman SH, Surprenant YM, Tang J. Synergistic effect of granulocyte-macrophage colonystimulating factor and 1,25-dihydroxyvitamin D3 on the differentiation of the human monocytic cell line U937. Blood. 1988;71:619-624.

56. Sugiura T, Kondo S, Kishimoto S, et al. Evidence that 2-arachidonoylglycerol but not N-palmitoylethanolamine or anandamide is the physiological ligand for the cannabinoid CB2 receptor: comparison of the agonistic activities of various cannabinoid receptor ligands in HL-60 cells. J Biol Chem. 2000;275:605-612.

57. Sugiura T, Kodaka T, Nakane S, et al. Evidence that the cannabinoid CB1 receptor is a 2-arachidonoylglycerol receptor: structure-activity relationship of 2-arachidonoylglycerol, ether-linked analogues, and related compounds. J Biol Chem. 1999;274:2794-2801.

58. Sugiura T, Waku K. 2-Arachidonoylglycerol and the cannabinoid receptors. Chem Phys Lipids. 2000;108:89-106.

59. Gonsiorek W, Lunn C, Fan X, Narula S, Lundell D, Hipkin RW. Endocannabinoid 2-arachidonyl glycerol is a full agonist through human type 2 cannabinoid receptor: antagonism by anandamide. Mol Pharmacol. 2000;57:1045-1050.

60. Lambert DM, DiPaolo FG, Sonveaux P, et al. Analogues and homologues of N-palmitoylethanolamide, a putative endogenous $\mathrm{CB}_{2}$ cannabinoid, as potential ligands for the cannabinoid receptors. Biochim Biophys Acta. 1999;1440:266274.
61. Derocq JM, Segui M, Marchand J, Le Fur G, Casellas $P$. Cannabinoids enhance human B-cell growth at low nanomolar concentrations. FEBS Lett. 1995;369:177-182.

62. Berdyshev EV. Cannabinoid receptors and the regulation of immune response. Chem Phys Lipids. 2000;108:169-190.

63. Lopez-Cepero M, Friedman M, Klein T, Friedman $H$. Tetrahydrocannabinol-induced suppression of macrophage spreading and phagocytic activity in vitro. J Leukoc Biol. 1986;39:679-686.

64. McCoy KL, Matveyeva M, Carlisle SJ, Cabral GA Cannabinoid inhibition of the processing of intact lysozyme by macrophages: evidence for CB2 receptor participation. J Pharmacol Exp Ther. 1999; 289:1620-1625

65. Wallace JM, Tashkin DP, Oishi JS, Barbers RG. Peripheral blood lymphocyte subpopulations and mitogen responsiveness in tobacco and marijuana smokers. J Psychoactive Drugs. 1988;20:9-14.

66. Rachelefsky GS, Opelz G, Mickey MR, et al. Intact humoral and cell-mediated immunity in chronic marijuana smoking. J Allergy Clin Immunol. 1976;58:483-490.

67. Nahas GG, Osserman EF. Altered serum immunoglobulin concentration in chronic marijuana smokers. Adv Exp Med Biol. 1991;288:25-32.

68. Schatz AR, Koh WS, Kaminski NE. $\delta$ 9-tetrahydrocannabinol selectively inhibits T-cell dependent humoral immune responses through direct inhibition of accessory T-cell function. Immunopharmacology. 1993;26:129-137.

69. Specter SC, Klein TW, Newton C, Mondragon M, Widen R, Friedman H. Marijuana effects on immunity: suppression of human natural killer cell activity of $\delta$-9-tetrahydrocannabinol. Int J Immunopharmacol. 1986;8:741-745.

70. Klein TW, Newton C, Friedman H. Inhibition of natural killer cell function by marijuana components. J Toxicol Environ Health. 1987;20:321-332.

71. McCoy KL, Gainey D, Cabral GA. $\delta$ 9-tetrahydrocannabinol modulates antigen processing by macrophages. J Pharmacol Exp Ther. 1995;273: 1216-1223.

72. Galiegue S, Mary S, Marchand J, et al. Expression of central and peripheral cannabinoid receptors in human immune tissues and leukocyte subpopulations. Eur J Biochem. 1995;232: 54-61.

73. Bouaboula M, Rinaldi M, Carayon P, et al. Cannabinoid-receptor expression in human leukocytes. Eur J Biochem. 1993;214:173-180. 